\title{
ANALISIS PENGENDALIAN KREDIT MACET PADA KSP BALO' TORAJA CABANG BUNTU KECAMATAN GANDANGBATU SILLANAN KABUPATEN TANA TORAJA
}

\section{Penulis \\ ${ }^{1}$ Jemi Pabisangan Tahirs \\ ${ }^{1}$ Universitas Kristen Indonesia Toraja \\ Email : sukranpratama@gmail.com}

\section{Info Artikel}

p-ISSN : 2615-1871

e-ISSN : $2615-5850$

Volume 2 Nomor 2, September 2019

\section{Received 3th August 2019/ Accepted 26th August 2019}

\begin{abstract}
ABSTRAK
Penelitian ini bertujuan untuk mengetahui pengendalian kredit macet pada KSP Balo' Toraja Cabang Buntu Kecamatan Gandangbatu Sillanan Kabupaten Tana Toraja. Penelitian ini menggunakan metode kualitatif dengan pendekatan studi kasus. Data yang digunakan dalam penelitian ini adalah data primer yang diperoleh dari hasil wawancara secara mendalam, observasi dan data sekunder yang terdiri atas beberapa dokumentasi yang diperoleh KSP Balota' Cabang Buntu Kabupaten Tana Toraja dan literatur yang terkait dengan penelitian. Data primer dalam penelitian ini diperoleh dari informan yakni manajemen dan nasabah koperasi. Hasil penelitian menunjukkan bahwa umumnya faktor penyebab kredit macet pada KSP Balo' Toraja Cabang Buntu disebabkan oleh debitur. Hal ini menunjukkan bahwa dana yang dipinjam oleh debitur belum optimal sesuai dengan pemamfaatannya.
\end{abstract}

Kata kunci: Pengendalian, Kredit Macet

\section{PENDAHULUAN}

Koperasi adalah badan hukum yang didirikan oleh orang perseorangan atau badan hukum koperasi, dengan pemisahan kekayaan para anggotanya sebagai modal untuk menjalankan usaha, yang memenuhi aspirasi dan kebutuhan bersama di bidang ekonomi, sosial dan budaya sesuai dengan nilai dan prinsip koperasi (UU No. 17 Tahun 2012 ayat 1 pasal 1). Perbedaan koperasi dengan badan usaha lainnya adalah koperasi memiliki identitas ganda yakni pemilik dan pengguna jasa koperasi itu sendiri. Selain meningkatkan kesejahteraan perekonomian anggotanya, koperasi juga dituntut meningkatkan sumber daya manusia agar kompeten dalam mengelola usahanya.

Kredit merupakan penyaluran dana dari pihak pemilik dana kepada pihak yang memerlukan dana. Penyaluran dana tersebut didasarkan pada kepercayaan yang diberikan oleh pemilik dan kepada pengguna lain. Pengertian kredit adalah kemampuan untuk 
melaksanakan suatu pembelian atau mengadakan suatu pinjaman dengan janji, pembayaran akan dilaksanakan pada jangka waktu yang telah disepakati. Menurut Suyatno Thomas (2012:5) fungsi kredit adalah Kredit dapat meningkatkan daya guna (utility) dari uang, Kredit dapat meningkatkan daya guna (utility) dari barang, Kredit meningkatkan peredaran dan lalu lintas uang, Kredit adalah salah satu alat stabilisasi ekonomi, Kredit menimbulkan kegairahan berusaha masyarakat, Kredit adalah jembatan untuk meningkatkan pendapatan nasional dan Kredit adalah juga sebagai alat hubungan ekonomi internasional.

Kredit macet yang terjadi tidak hanya disebabkan oleh nasabah akibat pendapatan usaha yang menurun dan ketidakpastian kondisi ekonomi, namun kredit macet juga ternyata dapat disebabkan kekeliruan/kesalahan koperasi dalam memberikan kredit macet kepada nasabah, seperti analisis terhadap kemampuan membayar nasabah yang keliru dan tidak sesuai prosedur yang telah ditetapkan, kelengkapan dokumen yang diperlukan bank yang kurang dipenuhi oleh nasabah namun disetujui oleh bank serta survei awal terhadap usaha yang dilaksanakan oleh nasabah yang kurang menyeluruh dan teliti yang disebabkan kelalaian/kesalahan yang dilakukan koperasi.

Salah satu cara agar permasalahan kredit macet dapat diatasi ialah dengan adanya suatu pengendalian internal yang sangat baik dalam hal pemberian kredit, dengan kata lain diperlukan adanya suatu pengendalian internal yang memadai dalam bidang perkreditan, dimana dengan adanya sistem pengendalian internal yang baik tersebut dapat mencerminkan sikap kehati-hatian dalam pemberian kredit tersebut (Mega, 2012:2). Pengendalian intern adalah usaha yang dilakukan untuk menjaga pemberian kredit tetap lancar, produktif dan tidak macet (Hasibuan, 2009:105). Tujuan dari adanya pengendalian intern yaitu menjaga agar kredit yang disalurkan tetap aman, mengetahui apakah kredit yang disalurkan itu tetap lancar atau tidak, melakukan pencegahan dan penyelesaian kredit macet (Hasibuan, 2009:105).

Dengan adanya sistem pengendalian internal yang baik diharapkan koperasi dapat mengukur apakah koperasi telah melaksanakan segala sesuatunya sesuai dengan aturan dan tidak menyimpang sehingga tujuan organisasi dapat tercapai dengan baik atau malah sebaliknya. Hal ini yang melatarbelakangi penelitian ini dilakukan di KSP Balo' Toraja Cabang Buntu Kabupaten Tana Toraja.

\section{METODE PENELITIAN}

Metode penelitian yang digunakan dalam penelitian ini adalah penelitian kualitatif dengan pendekatan studi kasus. Data yang digunakan dalam penelitian ini adalah data primer yang diperoleh dari hasil wawancara secara mendalam, observasi dan data sekunder yang terdiri atas beberapa dokumentasi yang diperoleh KSP Balota' Cabang Buntu Kabupaten Tana Toraja dan literatur yang terkait dengan penelitian. Data primer dalam penelitian ini diperoleh dari informan yakni manajemen dan nasabah koperasi. 


\section{HASIL DAN PEMBAHASAN}

\section{Analisis Kredit Macet}

Dengan adanya pengendalian kredit maka pihak koperasi akan melakukan kegiatankegiatan dalam menanggulangi kredit macet yaitu:

\section{Melakukan restrukturisasi kredit}

Restrukturisasi kredit adalah upaya perbaikan yang dilakukan dalam kegiatan perkreditan terhadap debitur yang berpotensi mengalami kesulitan untuk memenuhi kewajibannya. Kebijakan restrukturisasi kredit yang di lakukan koperasi antara lain melalui:

a. Penurunan suku bunga kredit.

Penurunan suku bunga kredit secara berlebih dapat menurunkan potensi keuntungan hingga tidak lagi menarik secara ekonomis bila di bandingkan dengan resiko kredit yang di resap. Bila hal ini terjadi, dapat menyebabkan koperasi enggan menyalurkan kredit.

b. Perpanjangan jangka waktu kredit.

Perpanjangan kredit merupakan fasilitas yang di berikan kepada debitur untuk menambah jangka waktu pelunasan kredit, karena kredit itu masih di perlukan debitur. Debitur masih diperbolehkan mengambil kredit jika masih ada saldonya dan maksimum kredit kembali seperti semula.

c. Pengurangan tunggakan bunga kredit.

Suatu solusi atau upaya perbaikan yang di lakukan koperasi dalam kegiatan mengurangi bunga kredit terhadap debitur yang mengalami kesulitan untuk memenuhi kewajibannya.

d. Penambahan fasilitas kredit.

Kredit merupakan fasilitas terbaik saat ini. Namun jika kredit masih belum mampu untuk dibayar, maka seorang konsumen bisa berkonsultasi kepada koperasi dan meminta untuk di tambah fasilitas kredit. Contohnya dengan membagi pembayaran lebih kecil sehingga tidak membaratkan konsumen.

Terdapat beberapa persyaratan untuk mengajukan restrukturisasi kredit kepada koperasi yaitu:

1. Debitur mengalami kesulitan pembayaran pokok dan bunga kredit.

2. Debitur memiliki prospek usaha yang baik dan dinilai mampu memenuhi kewajiban setelah kredit di restrukturisasi.

\section{Melakukan negosiasi penyelesaian kredit}

Negosiasi dapat di lakukan terhadap debitur yang beritikad baik untuk menyelesaikan kewajibannya dan cara yang di tempuh dalam penyelesaian ini di anggap lebih baik di bandingkan alternatif penyelesaian melalui sarana hukum. Ada beberapa macam penyelesaian melalui negosiasi di antaranya adalah

1). Pemberian keringanan dalam pembayaran angsuran, debitur diberi kesempatan untuk membayar angsuran dalam jumlah lebih kecil dari ketentuan yang seharusnya.

2). Pemberian kesempatan pelunasan hutang sebagian, debitur dapat membayar sebagian jumlah hutang keseluruhan. 
3). Penjualan agunan di bawah tangan, di lakukan agar debitur masih di berikan kesempatan untuk menawarkan/menjual sendiri agunannya untuk melakukan pelunasan pembayaran hutang sebagian maupun secara keseluruhan.

\section{Penjualan jaminan/agunan}

Benda yang di jadikan barang jaminan (agunan) tidak harus di serahkan secara aktual, tetapi boleh juga penyerahannya secara hukum, seperti menjadikan sawah sebagai jaminan (agunan), yang di serahkan adalah surat jaminannya (sertifikat sawah). Oleh sebab itu, kredit terkaid dengan barang jaminan, apabila kredit tidak di lunasi barang jaminan dapat di jual dan kredit dibayar. Apabila dalam penjualan barang jaminan itu ada kelebihan, maka wajib di kembalikan kepada pemiliknya.

Pelaksanaan penjualan barang jaminan di dasari dengan adanya mekanisme tertentu berupa perjanjian pembiayaan yang di lakukan oleh seseorang atau koperasi untuk mendapatkan sejumlah dana, melalui mekanisme pemberian kredit dan debitur kepada kreditur.

\section{Pengendalian Kredit Macet}

Langkah-langkah pengendalian kredit macet adalah:

1. Komunikasi melalui telpon/SMS

Pihak koperasi akan menghubungi anggota yang mengambil kredit melalui telfon/SMS.

2. Melakukan kunjungan ke anggota koperasi

Apabila anggota koperasi tidak membayar kredit tepat waktu maka pihak koperasi akan melakukan kunjungan kerumah anggota untuk meminta jaminan yang telah di sepakati sebelum mengambil kredit.

3. Dibuatkan surat panggilan

Apabila pihak koperasi sudah melakukan langkah pertama yaitu menghubungi anggota yang mengambil kredit tetapi anggota tersebut sama sekali tidak membayar kredit maka pihak koperasi akan melakukan cara kedua yaitu melakukan kunjungan kerumah anggota untuk meminta jaminan yang sudah disepakati sebelumnya dan kemudian pihak koperasi akan melakukan cara yang ketiga yaitu dengan membuatkan surat peringatan dan jika anggota koperasi belum juga membayar kreditnya maka pihak koperasi akan mengambil jaminan yang sudah di sepakati sebelum mengambil kredit.

Faktor yang menyebabkan kredit macet pada KSP Balo' Toraja Cabang Buntu Kabupaten Tana Toraja.

Terjadinya kredit macet dapat disebabkan oleh berbagai macam faktor, dapat disebabkan oleh kesengajaan sehingga sehingga menyebabkan debitur mengalami kesulitan dalam memenuhi kewajibannya. Berdasarkan penelitian yang dilakukan oleh penulis diketahui terdapat beberapa penyebab terjadinya kredit macet diantaranya sebagai berikut:

a. Faktor internal dari koperasi

1. Penganalisaan perkreditan yang kurang tepat

Hal ini terjadi apabila pihak analisis kredit kurang disiplin dalam menerapkan prosedur perkreditan sesuai dengan pedoman dan tata cara pemberian kredit, sehingga 
mengakibatkan penyimpangan dalam sistem dan prosedur perkreditan yang pada akhirnya menyebabkan penilaian terhadap debitur tidak optimal.

2. Kebijakan perkreditan yang kurang selektif

Adanya kebijakan koperasi tentang target jumlah kredit yang harus direalisasi dalam kurun waktu tertentu mendorong pihak pemutus kredit menempuh jalan yang tidak sesuai dengan ketentuan dalam menyalurkan kredit. Sehingga mengakibatkan kurang selektifnya dalam memilih calon nasabah.

b. Faktor dari debitur

1. Debitur mengalami musibah

Adanya musibah yang dialami oleh debitur misalnya meninggal dunia, akan tetapi pihak keluarga tidak memberikan informasi kepada koperasi. Hal ini bisa menghambat ketepatan waktu pembayaran angsuran kredit dan menyebabkan koperasi mengalami kerugian.

2. Kelemahan manajemen usaha yang dijalankan debitur

Merupakan kelemahan debitur dalam melenkukan perencanaan, pengorganisasian, serta pengontrolan terhadap kegiatan usaha yang dilakukan.

3. Ketidak jujuran debitur dalam mengelolah kredit

Apabila debitur melakukan penyelewengan terhadap dana kredit yang didapatkannya, misalnya dalam pengajuan kredit.

4. Debitur mengalami pemutusan hubungan kerja

Debitur yang bekerja pada koperasi terkena pemutusan kerja, sehingga tidak mempunyai penghasilan guna memenuhi kewajiban kreditnya.

5. Itikad yang tidak baik oleh debitur

Debitur melarikan diri tanpa sepengetahuan dari pihak koperasi yang menyebabkan pembayaran angsuran kredit menjadi terhambat.

c. Faktor internal dari pihak koperasi dan debitur

1. Bencana alam

Apabila terjadi kebakaran pada tempat usaha debitur sehingga debitur tidak bisa menjalankan kegiatan operasional usahanya atau mengalami kebangkrutan.

2. Keadaan kondisi perekonomian

Perubahan-perubahan eksternal yang dialami yaitu perubahan peraturan pemerintah, kenaikan harga-harga maupun kenaikan biaya produksi menyebabkan kesulitan pada usaha yang dijalankan debitur.

\section{Pengendalian kredit macet pada KSP Balo' Toraja Cabang Buntu Kabupaten Tana}

\section{Toraja.}

KSP Balo' Toraja Cabang Buntu melakukan upaya-upaya menangani dan menyelamatkan kredit macet, kebijakan yang dilakukan pihak KSP Balo' Toraja Cabang Buntu terdiri dari kebijakan para realisasi kredit yaitu upaya pencegahan kredit macet dengan penganalisaan calon debitur dan kebijakan setelah pasca realisasi kredit yang terdiri dari 
beberapa tahap yaitu pengendalian secara nonlitigasi dan pengendalian secara litigasi (hukum)

Pengendalian kredit macet pada KSP Balo' Toraja Cabang Buntu bersifat antisifasif, proaktif dan berdisiplin yang dituntut adanya pengenalan dini atas tanda adanya kredit macet dan mengambil tindakan cepat sebelum kredit semakin bertambah parah. Oleh karena itu dalam hal pengendlian kredit macet pada KSP Balo' Toraja Cabang Buntu sebelumnya telah mengelompokkan kualitas kredit berdasarkan kolektibitas debitur dalam membayar angsuran kreditnya, hal ini dilakukan agar pihak koperasi dapat menentukan kebijakan-kebijakan yang akan diambil presedur pengendalian kredit macet. Adapun pengelompokan kolektibilitas kredit yang dilakukan KSP Balo' Toraja Cabang Buntu adalah sebagai berikut:

a. Lancar (L) apabila debitur sama sekali tidak ada tunggakan dalam mengangsur kreditnya.

b. Kurang lancar (KL) apabila debitur mengalami tunggakan angsuran selama 91-120 hari atau selama 3-4 bulan.

c. Diragukan (D) apabila debitur mengalami tunggakan angsuran selama 121-180 hari atau 4-8 bulan.

d. Macet (M) apabila debitur mengalami tunggakan angsuran selama 181-999 hari atau lebih.

Tahapan-tahapan dalam penyelamatan dan penyelesaian kredit macet pada KSP Balo' Toraja Cabang Buntu Kecamatan Gandangbatu Sillanan Kabupaten Tana Toraja

1. Pembinaan Kredit

Pembinaan ini merupakan upaya-upaya yang dilakukan koperasi agar debitur pembiayaan dapat memenuhi kewajibannya sebagaimana dituangkan dalam perjanjian kredit sehingga pembayaran angsuran bisa dilakukan secara tertib dan teratur.

2. Restrukturisasi kredit

Apabila pihak koperasi telah berupaya melakukan pembinaan kepada debitur yang memiliki kredit macet, namun tidak berhasil maka pihak koperasi akan menyarankan solusi alternatif kepada debitur untuk melakukan restrukturisasi kredit.

Dalam melakukan restrukturisasi pihak koperasi dan pihak debitur akan membuat akta perjanjian kredit yang baru yang merubah tentang besaran angsuran jangka waktu bunga dan lain sebagainyayang berhubungan dengan pola restrukturisasi yang dilakukan. Hal yang penting dalam melakukan restrukturisasi kredit adalah koperasi yang memahami bidang usaha, kondisi bisnis dan masalah yang dihadapi debitur, ini diperlakukan untuk menentukan langkah restrukturisasi yang tepat dan mecari solusi bagi yang dihadapi oleh debitur.

\section{SIMPULAN DAN SARAN}

Berdasarkan hasil penelitian diketahui bahwa umumnya faktor penyebab kredit macet pada KSP Balo’ Toraja Cabang Buntu disebabkan oleh debitur. Hal ini menunjukkan bahwa dana yang dipinjam oleh debitur belum optimal sesuai dengan pemamfaatannya. Untuk itu KSP Balo' Toraja Cabang Buntu perlu meningkatkan kinerja SDM dalam melakukan pembinaan debitur guna meminimalkan resiko yang terjadi akibat dari kredit macet. 


\section{DAFTAR PUSTAKA}

Thomas, Suyatno dkk, (2012), Dasar-Dasar Perkreditan, Jakarta: Gramedia Pustaka

Dafi, Armahedi, (2011). Analisis Efektivitas Pengendalian Kredit (Studi Pada Koperasi Marsudi Mulyo), Fakultas Ekonomi Dan Bisnis, Universitas Dian Nuswantoro Semarang.

Hasibuan, Melayu. (2009). Dasar-dasar Perbankan. Jakarta: Bumi Aksara

Irwan, I., \& Haryono, D. (2015). Pengendalian Kualitas Statistik (Pendekatan Teoritis dan Aplikatif). Bandung: Alfabeta

Kasmir, (2000), Bank Dan Lembaga Keuangan Keuangan Lainnya, cetakan keenam, Jakarta: PT Raja Grafindo persada.

Norman, Syah Putra; Agus Widarsono; Arim Nasim. Analisis Penerapan Sistem Pengendalian Internal Untuk Mencegah Kredit Macet Pembiayaan Musyarakah Modal Kerja Yang Diberikan Oleh Bank. Jurnal Aset, Akuntansi Riset, 5 (2), 2013; 1-10.

Sinungan, Munchdarsyah, (2000), Strategi Manajemen Bank, cetakan pertama. Jakarta: Rineka Cipta

Tenrigau, A. M., dkk. (2018). Manajemen Sebuah Pengantar. Palopo: Andi Djemma Press 